\title{
ZNIKAJĄCE ZNAKI. CZY MOŻNA PRZEŚLEDZIĆ LOSY POLSKICH HERBÓW RYCERSKICH W ŚWIETLE ŹRÓDEE ŚREDNIOWIECZNYCH?
}

\author{
Mateusz Gigoń \\ kliper@gazeta.pl
}

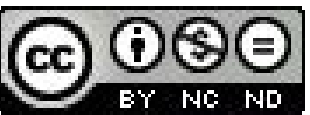

Jednym z celów nowoczesnej heraldyki jest rekonstrukcja struktury społeczeństwa średniowiecznego - wraz z genealogią poszukuje odpowiedzi na pytanie o rolę rodów rycerskich. Widomym znakiem spójności rodu jest herb - dziedziczny, ustalony znak kładziony w tarczy i nazwany danym mianem. W średniowiecznej heraldyce polskiej dodatkowym istotnym elementem herbu jest znamię głosowe, czyli zawołanie proclamatio ${ }^{1}$. Herb wyodrębnia pewną grupę (ród) z szerszej społeczności (lokalnej, regionalnej, państwowej), nadaje jej granice, w związku z czym powstaje kwestia utożsamiania lub rozdzielania herbów - a co za tym idzie rodów². O rodach rycerskich jako realnych, zwartych (stosunkowo) stronnictwach politycznych i solidarnych grupach społecznych pisał Janusz Bieniak ${ }^{3}$. Niniejszy artykuł ma za zadanie przyjrzeć się aspektowi heraldycznemu rodów średniowiecznych, a konkretniej - trudnościom, jakie stawiają źródła przed badaczem tej dziedziny.

Powstanie herbu jako znamienia rodu stanowi proces dla każdego rodu oddzielny - w zależności od pozycji społecznej danej gens trwać mógł dwa-trzy pokolenia lub zakończyć się de facto w XVI w. ${ }^{4}$. Herb wywodzi się z indywidualnych znaków własnościowych kładzionych przeważnie na pieczęciach rycerstwa XIII-wiecznego. Charakterystyczne dla poszczególnych osób, stają się w pewnym momencie znakami dziedzicznymi, umieszczanymi w tarczy - od tego momentu, przypadającego na przełom XIII i XIV w., możemy mówić o herbie. W toku XIV stulecia wykształca się ostateczny kształt herbu ${ }^{5}$, a jeszcze w XV w. - poprzez redukcję mniej popularnych haseł nazwy rodów, herbów i zawołania ${ }^{6}$. Zaznaczyć trzeba, że chronologia powyższa dotyczy przeważnie arystokracji. Rody drobnorycerskie do XVI w. posługują się często wieloma odmianami herbu, nazwami rodu i zawołaniami? Słabo oświetlone w źródłach sprawiają badaczom problem - czy mamy do czynienia z osobnym rodem, czy też z gałęzią rodu, a jeśli tak, to którego?

Chciałbym wrócić teraz do pieczęci XIII-wiecznych. Przedstawiały one kombinacje kreskowe, krzyże, pierścienie, połupierścienie, które stać się mogły punktem wyjścia do utworzenia postaci herbu znanej nam z czasów późniejszych. Jednakże w danym czasie funkcjonowało kilka odmiennych znaków spokrewnionych ze sobą osób. Dopiero zdobycie przewagi politycznej przez danego przedstawiciela rodu lub daną jego gałąź wymuszało na pozostałych członkach

1 J. Szymański, Nauki pomocnicze historii, Warszawa 2004, s. 653.

Powyższe uwagi dotyczące społecznej roli herbu odnoszą się do XIV-XV w.

J. Bieniak, Rody rycerskie jako czynnik struktury społecznej w Polsce XIII-XV wieku (uwagi problemowe), [w:] tenże, Polskie rycerstwo średniowieczne, Kraków 2002, s. 71-79; także: tenże, Jeszcze w sprawie genezy rodów rycerskich w Polsce, [w:] tenże, Polskie rycerstwo..., dz. cyt., s. 123-130.

4 J. Bieniak, Rody..., dz. cyt., s. 64; tenże, Heraldyka polska przed Długoszem. Uwagi problemowe, [w:] tenże, Polskie rycerstwo..., dz. cyt., s. 109 i nast.; J. Wroniszewski, Kryteria herbowe w badaniach genealogicznych, [w:] J. Hertel, (red.) Genealogia. Problemy metodyczne w badaniach nad polskim społeczeństwem średniowiecznym na tle porównawuczym, Toruń 1982, s. 121.

J. Wroniszewski, dz. cyt., s. 122

J. Bieniak, Heraldyka..., dz. cyt., s. 85-109, zwł. 93, 106-107.

J. Wroniszewski, dz. cyt., s. 129. 
przyjęcie jednego znaku${ }^{8}$. Mogła to być stara kombinacja kresek, przekształcona w procesie geometryzacji na proste mobilia herbowe (podkowa, krzyż, miecz itp.) - jak w przypadku Pobogów, których najstarsze pieczęcie przypominają XIV-XV-wieczną podkowę z krzyżem;' lub też zupełnie nowe godło ${ }^{10}$, wprowadzone przez jednego z członków rodu np. Wierzbnów, którzy zaczęli pieczętować się pasem i liliami ${ }^{11}$. Pozostałe znaki napieczętne są - nawiązując do tytułu artykułu - pierwszymi, które „zniknęły”, choć wspominając o nich pamiętać należy, że nie wszystkie były herbami. Jeszcze bowiem w XIV w. trwa „rywalizacja” godeł, zarówno w rodach znamienitszych, jak i pośledniejszych ${ }^{12}$.

Owe konkurencyjne godła stają się przyczyną nieporozumień w dzisiejszej nauce, która rozdziela czasem dwie odmiany jednego herbu ${ }^{13}$. Dodatkowo trzeba podnieść kwestię dokładności, a raczej jej braku, z jaką opisywane były herby w źródłach sądowych, stanowiących często jedyną informację o danym clenodium ${ }^{14}$. Z kolei Alicja Szymczakowa zwraca uwagę, że „chwiej-

8 J. Bieniak, Problemy metodyczne średniowiecznej genealogii w Polsce, [w:] tenże, Polskie rycerstwo..., dz. cyt., s. 32-33; tenże, Heraldyka..., dz. cyt., s. 109-113.

9 J. Bieniak, Heraldyka..., dz. cyt., s. 113; w tej sprawie por. F. Sikora, O rzekomej dominacji politycznej Lisów w Matopolsce w XIII wieku, czyli kilka uwag o rodzie Pobogów, "Studia Historyczne” 1983, XXVI, z. 1; ostatnio W. Zawitkowska, O herbie Pobóg w XV wieku. Na marginesie badań nad dziejami Koniecpolskich w późnym średniowieczu, „Rocznik Towarzystwa Heraldycznego nowej serii” [dalej: RTH ns i RTH dla "Rocznika Towarzystwa Heraldycznego" ukazującego się przed Drugą Wojną Światową] 2005, VII.

${ }_{10}$ "Godło" oznacza znak w tarczy herbu, choć J. Wroniszewski wykazał zupełnie inne znaczenie tego terminu w średniowieczu - oznaczano tym terminem zawołanie. J. Wroniszewski, Proclamatio alias godlo. Uwagi nad geneza i funkcją zawołań rycerskich w średniowiecznej Polsce [w:] Społeczeństwo Polski średniowiecznej, t. IV [W literaturze przyjęto podawanie numerów tomów przytoczonych wydawnictw źródłowych za pomocą cyfr rzymskich. Cyfry arabskie oznaczają numer cytowanej zapiski], Warszawa 1990.

11 T. Jurek, Panowie z Wierzbnej, Kraków 2006, s. $94-97$ upatruje źródeł tej zmiany w prawdopodobnym pobycie Jana z Wierzbnej na studiach w Paryżu, gdzie zetknął się z ikonografią Kapetyngów.

12 J. Wroniszewski, Kryteria..., dz. cyt., s. 122.

13 Z pewną obawą piszę o „odmianach” w polskiej heraldyce, gdyż problem ich nie stał się tematem osobnego opracowania. Brakuje definicji odmiany herbowej, w nauce przyjęto chyba milczące założenie, że mamy do czynienia z odmianami jakby czasowymi, związanymi z procesem ujednolicania się herbu - por. stwierdzenie J. Bieniaka: „odmiany barwne nie tworzyły jednak odrębnych herbów", tenże, Heraldyka..., dz. cyt., s. 121, mimo iż sam pisze o różnych barwach herbu Grzymałów i Pogorzelów - tamże, s. 117. Odmianę jako zjawisko bardziej trwałe przyjmuje chyba W. Zawitkowska, dz. cyt., s. 27: „,możliwe jest zatem, że już w latach 30. XV w. istniały co najmniej dwie odmiany herbu Pobóg". Definicję próbował ułożyć A. Małecki, Studya heraldyczne, t. II, Lwów 1890, s. 285 - „odmiany niektórych godeł, osiągane w ten sposób, że do ich formy zwykłej (...) przybierano pewne dodatki, które im nadają postać mniej więcej odrębną". Późniejsza nauka, traktowała ten temat obocznie - F. Piekosiński uważał ich istnienie za naturalną konsekwencję rozradzania się rodu, w którym najstarszy syn dziedziczył znak po ojcu, a młodsi go odmieniali. W. Semkowicz patrzył na sprawę nieco trzeźwiej uznając istnienie odmian jako konsekwencji rozkładu świadomości rodowej. Poglądy Piekosińskiego i W. Wittyga ostro skrytykowała H. Polaczkówna. M. Cetwiński uważa, że odmiany były w Polsce średniowiecznej przyjmowane dość naturalnie, ponieważ każdy ród jest z innymi spokrewniony, a jedne herby wywodzą się od drugich. Stanowisko J. Bieniaka zasygnalizowałem na początku tego przypisu.

F. Piekosiński, Heraldyka polska wieków średnich, Kraków 1899, s. 6; W. Semkowicz, Długosz jako heraldyk, „,Miesięcznik Heraldyczny" [dalej: MH] 1908, R. I, z. 1, s. 7; H. Polaczkówna, Recenzja W. Wittyg, Nieznana szlachta polska i jej herby, MH, 1909, R. II, z. 5, s. 77-79; M. Cetwiński,Wokót „Klejnotów", [w:] J. Hertel (red.), Genealogia. Studia nad wspólnotami krewniaczymi i terytorialnymi w Polsce średniowiecznej na tle porównawczym, Toruń 1987, s. 129-131.

${ }_{14}$ Z 1478 r. pochodzi zapiska przemyska, w której Piotr i Iwan z Chłopczyc opisali swój herb jako „Vilczkossy et duabus crucibus et luna”. W 1414 r. w Krakowie świadczyli Andrzej z Druszkowa i Mikołaj z Osia „de clenodio Ignilis (...) medij nigri griffonis" oraz Jan Franczuch z Nosaczowic i Wyszko z Druszkowa "de clenodio curwature et altere medie crucis". W 1412 r. także w Krakowie Wacław i Wawrzyniec z Cudzinowic opisali swój herb jako „duorum babatorum et crucis". Nie wiadomo jak te wszystkie mobilia miały być umieszczone względem siebie na tarczy. Na uwagę zwraca podanie koloru gryfa w drugiej zapisce. Barwy pojawiają się w źródłach sądowych stosunkowo rzadko. Akta grodzkie i ziemskie z czasów Rzeczypospolitej Polskiej z archiwum tak zwanego bernardyńskiego we Lwowie, t. XVIII, Lwów 1903, s. 165, nr 1084 [dalej 
ność nomenklaturowa charakterystyczna dla piętnastowiecznej heraldyki powoduje niekiedy mnożenie herbów"15. Wszystkie te trudności mają swoje źródło w procesie tworzenia rodów heraldycznych - jeśli ród genealogiczny był bardzo rozrodzony, to proces unifikacji godła się wydłużał, tym bardziej im mniej znaczny był ród; z drugiej strony - jeśli mamy do czynienia z rodem sztucznie utworzonym (lub mającym w sobie wiele elementów genealogicznie obcych), to pozostające w użyciu godła są reminiscencją poprzedniej odrębności ${ }^{16}$. Inną kwestią jest stan i liczba zachowania źródeł średniowiecznych - zarówno ikonograficznych, jak i pisanych. Często natykamy się na jedną tylko wzmiankę o herbie lub też jego oderwany wizerunek. Nie wiadomo co wtedy począć, ale postępujące badania (czasem rehabilitujące zapomniane tezy sprzed lat) pokazuja, że można uzupełnić pewne, wydawałoby się ostateczne, ustalenia ${ }^{17}$.

Szereg korekt poczynili Alicja i Jacek Szymczakowie dzięki kwerendzie w księgach sieradzkich $i$ badaniom epigraficznym ${ }^{18}$. Umożliwiły one identyfikację osób pojawiających się w zapiskach sądowych przy okazji raz tylko wspomnianych herbów: Kliza ${ }^{19}$ i Wiza. Okazuje się, że świadczący z pierwszego z nich w $1399 \mathrm{r}$. Jarosław z Remiszewic miał wnuka o takim samym imieniu, świadczącym z herbu Jelita. Ponadto imiennictwo Klizów i Jelitczyków jest podobne, co skłania do stwierdzenia tożsamości tych herbów (mimo pewnej różnicy znaków - co dopuszcza J. Wroniszewski²0). Z kolei z klejnotu Wiza świadczył w 1398 r. w procesie swego krewnego Bartłomiej z Rdułtowic, dwukrotnie później (1405 i 1410 r.) nazwany Ostoją. Następnie A. Szymczakowa przypomina (zauważyła to już J. Chwalibińska ${ }^{21}$ ), że nazwa Moszczenica nie oznacza osobnego herbu, ale jest proklamą Wilczychkos - do znanej skądinąd rodziny o przydomku Koysz, używającej tego zawołania ${ }^{22}$ A. Szymczakowa dodaje Wspinków z Będkowa. Ich protoplasta Piotr świadczył w 1405 r. jako

AGZ i nr tomu]; Starodawne prawa polskiego pomniki. Z ksiag rękopiśmiennych dotad nieużytych główniej zaś z ksiag dawnych sadowych ziemskich i grodzkich, t. II, Kraków 1870, nr 1330 [dalej: SPPP II]; Starodawne prawa polskiego pomniki. Inscriptiones clenodiales ex libris iudicalibus palatinus cracoviensis, ed. B. Ulanowski, t. VII, Kraków 1885, nr 219 [dalej: SPPP VII].

15 A. Szymczakowa, Drobiazgi heraldyczne z Sieradzkiego, RTH ns, 2001, V, s. 125.

16 Por. J. Wroniszewski, Kryteria ..., dz. cyt., s. 129. Istnieją dwie teorie powstania rodów heraldycznych - genealogiczna głosząca powstanie rodu w wyniku naturalnych procesów rozradzania się; i klientarna, zakładająca łączenie się kilku drobnych rodów w jeden większy. Obecnie większość badaczy przychyla się do tej pierwszej, choć dopuszcza wyjątki: większe rody mogły przyjmować mniejsze familiae, ale także pamiętać trzeba o całkowicie sztucznych rodach Prusów i Sasów-Dragów. J. Bieniak, Problemy metodyczne..., dz. cyt., s. 37-39; inaczej: M. Cetwiński, Pochodzenie etniczne i więzy krwi rycerstwa ślaskiego, [w:] Społeczeństwo Polski średniowiecznej, t. I, Warszawa 1985, s. 40-85; O Prusach i Sasach-Dragach pisali: J. Chwalibińska, Ród Prusów w wiekach średnich, Torun 1948 i L. Wyrostek, Ród Sasów-Dragów na Wegrzech i Rusi Halickiej, RTH, 1931-1932, XI, s. 1-191.

17 A. Szymczakowa, dz. cyt., s. 125-131; J. Sperka, Nieznana plyta grobowa w kościele parafialnym w Moskorzewie: przyczynek do dziejów Moskorzerwskich i Ważyńskich herbu Pilawa, RTH ns, 2003, VI, s. 101-108; J. Karczewska, Nieznane zapiski herbowe z wielkopolskich ksiag sadowych, RTH ns, 2005, VII, s. 111-115; L. Kajzer, Herby na kaflach z zamku w Ujeździe, czyli o zagadnieniu ",herbarzy ceramicznych", "Kwartalnik historii kultury materialnej” 2007, LV, z. 1, s. 21-31; W. Fronczak, O herbie Piękostki, „Gens”, 2007-2008, s. 83-90; P. Stróżyk, Barwne herby na średniowiecznej chrzcielnicy z katedry w Gnieźnie, „Roczniki historyczne" 2008, LXXIV, s. 179-192.

${ }_{18}$ Por:. J. Szymczak, Epigrafika w stużbie genealogii. O poczatkach Wspinków z Bẹdkowa, „Annales Universitatis Mariae Curie-Skłodowska” 1990, Historia XLV, oraz tenże, Erekcja kościoła $w$ podłódzkich Chojnach $w 1492$ r., "Rocznik Łódzki” 1996, XLIII; A. Szymczakowa, dz. cyt., s. 129-131.

19 Nazewnictwo herbów przyjmuję za J. Szymański, Herbarz średniowiecznego rycerstwa polskiego, Warszawa 1993, choć np. w sprawie herbu Owad badacz ten nie jest konsekwentny: nazwę podaje w rodzaju męskim (Owad - s. 216), ale później odmienia ją w rodzaju żeńskim („identyfikuje Owadę z Uliną" - przyp. 4 do hasła Owad). J. Wroniszewski, Kryteria, s. 125, przyjmuje tą drugą wersję, dlatego również będę używał nazwy rodzaju żeńskiego.

${ }^{20} \mathrm{~J}$. Wroniszewski, Kryteria.

21 J. Chwalibińska, dz. cyt., s. 80, 121

22 F. Piekosiński, Nieznane zapiski heraldyczne średniowieczne polskie, głównie sieradzkie, Archiwum Komisji Historycznej Akademii Umiejętności, t. VIII, 1898, nr 22 
Moszczenica, jego potomkowie są dobrze poświadczeni jako Wilczekosy²3. Dalsze ustalenia A. i J. Szymczaków dotyczą herbu Sulima, błędnie odczytanego jako Calina. Ten ostatni herb jest po prostu paleograficzną pomyłką. Błędnie wiązano też zawołanie Wazanki z Wilczymikosami (Prusem II) ${ }^{24}$. W 1404 r. Mszczuj z Będkowa określił swój herb właśnie jako Wazanki, ale pochodził on z innego Będkowa (pow. sieradzki) niż siedzący w tak samo nazwanej miejscowości (pow. brzeziński) Wilczekosy. Mszczuj miał brata Stanisława, który używał przydomków: Wężyk i Małdrzyk. Od niego pochodzą sieradzcy Wężykowie, a więc Wazanki to określenie rodu noszącego w herbie Węża, zawołania Zachorz. Podobny błąd popełniono - według W. Fronczaka ${ }^{25}$ - łącząc źródła ikonograficzne i narracyjne wspominające o herbie Piękostki. Jan Długosz w Księdze uposażeń biskupstwa krakowskiego wymienia dziedziców Mikułowic i Wielkanocy herbu „Pyakostky"26. Z tą wzmianką połączono tablicę erekcyjną w kościele w Wojciechowicach (zwanych kiedyś Mikułowicami) ${ }^{27}$, na której widnieje herb mający w godle coś na kształt cyfry $8 \mathrm{z}$ wystającymi z boków krzyżykami ${ }^{28}$. Jednakże owe Wojciechowice-Mikułowice znajdują się niedaleko Opatowa, zaś Długosz wyraźnie pisze o Mikułowicach koło Buska! W tej sytuacji przywołać można hipotezę S. Dziadulewicza, który połączył Piękostki z Mądrostkami, na podstawie herbu, jaki dziedzice Wielkanocy (drugiej z wsi wspomnianych przez Długosza) używali w połowie XVI w.29. Tym herbem były właśnie Mądrostki ${ }^{30}$.

Jan Wroniszewski, $w$ wielokrotnie przeze mnie przywoływanym artykule o kryteriach herbowych, zestawił kilka par herbów, które - podobnie jak Klizę z Jelitami czy Piękostki z Mądrostkami - możemy ze sobą utożsamić na podstawie identyczności osób świadczących z jednego i drugiego clenodium. I tak Jan z Jaszowic i Mikołaj z Jaszowic świadczą: jeden z herbu Ulina, drugi z herbu Owada ${ }^{31}$. Oba herby przedstawiają majuskułę M, przy czym Ulina ma na niej zaćwieczony krzyżyk, Owada - koronę. Sam J. Szymański w swym herbarzu przyznaje, że herby się utożsamiły - ,zapiska z 1445 nazywa Uliną herb, który już jest Owadą (...) zaś z 1453 (...) pomija krzyż"32. Podobnie ma się sprawa z herbami Czawuja i Kołmasz - „w 1409 r. Andrzej z Deszna wywodzi się z herbu Kolmasz, zaś w 1455 r. jego syn Wojciech (...) z rodu Czewoja. Podobnie w latach 1328 i 1429 świadczył w procesach o nagany Florian z Waźlina zawołania i herbu Kolmasz, a jego brat Mikołaj, naganiony w 1430 r. przywiódł dwóch rycerzy z rodu ojca de clenodio duorum babatorum et crucis in medio ac proclamacione Czawgia" ${ }^{\prime \prime 3}$.

Tu warto wtrącić dygresję o herbie Prus. Ród ten powstał w wyniku konsolidacji osadników i jeńców pruskich wokół przywilejów rodowych z połowy XIV w., zapewniającym niektórym $\mathrm{z}$ nich prawo rycerskie. Jest to ród całkowicie sztuczny, złożony $\mathrm{z}$ drobnych rodzin rozsianych w pasie od Wielkopolski przez ziemię sieradzka, Mazowsze i ziemię dobrzyńską. W XV w. wchłonęli dodatkowo małopolski, prawdopodobnie etnicznie słowiański, ród Turzynitów i już na po-

23 W. Fronczak, Programy heraldyczne w będkowskim kościele-próba wyjaśnienia, „Gens”, 2005-2006, s. 9 i przyp. 15 i 17 wskazuje jednak, że odpowiednie zapiski znane były już na przełomie XIX i XX wieku.

24 S. Dziadulewicz, Drobiazoi heraldyczne. 5. Herb Wążanki, RTH 1921-1923, VI, s. 135-136

25 W. Fronczak, O herbie..., dz. cyt., s. 88-89.

26 Zresztą we wsiach naokoło Wielkanocy siedzieli sami Mądrostkowie, a pleban w Baczkowicach zwał się „,Mikulowsky nobilis de domo Mądrostkhy" - Joannis Długosz, Opera omnia, ed. A. Przezdziecki, t. VIII, Liber beneficiorum dioecesis cracoviensis, [dalej: Liber beneficiorum] t. II, Cracov 1864, s. 39; Tamże, s. 433

27 W. Fronczak, O herbie..., dz. cyt. s. 84

28 Tamże; J. Szymański, dz. cyt., s. 218

29 Tamże, s. 86, 88

30 S. Dziadulewicz, Ze studiów nad heraldyką. Herb Piękostki, MH, 1912.

31 J. Wroniszewski, Kryteria..., dz. cyt., s. 125.

32 J. Szymański, Herbarz..., dz. cyt., s. 282, przyp. 4 do hasła Ulina.

33 J. Wroniszewski, Kryteria..., dz. cyt., s. 125-126. 
czątku tego stulecia de clenodio Prussi wywodzili się posiadacze trzech różnych godeł: półtora krzyża (Prus I), Wilczekosy (Prus II) oraz podkowa (później połupodkowa z wilcząkosą) z półtorakrzyżem (Prus III). Sądząc ze wspólnej nazwy rodowej (a była ona w tym czasie jednym z koniecznych elementów istnienia rodu heraldycznego $\left.{ }^{34}\right)$, mamy do czynienia z jednolitą społecznością wpisującą się w rzeczywistość prawno-polityczną kraju, w jego strukturę społeczną itp. Jednakże z 1434 r. pochodzi zapiska sądowa, z której dowiadujemy się, że aby udowodnić swoje szlachectwo Piotr z Pańszczycy zawezwał świadków: z własnego herbu (Błożyna) oraz z herbów Wilczekosy i Prus ${ }^{35}$. Oznaczać by to mogło, że Prus II i Prus I to dwa odrębne clenodia, nic ze sobą wspólnego nie mające. Rozwiązania tej sprawy są dwa: pierwsze zakłada, że do wywodu szlachectwa w sieradzkiem potrzebowano klejnotników z rodu własnego, z rodu matki i babki ojczystej - jednak analiza zapisek sieradzkich odrzuca tą możliwość; aby znaleźć drugie rozwiązanie trzeba przyjrzeć się źródłom. Występujący w zapisce z 1434 r. Wilczekosy - Jan Koysz z Wodzynia i Jakub Zacharski występują jeszcze później, lecz ani razu (także wcześniej!) nie użyli proklamy „Prus”36. Mamy więc do czynienia z wyjątkowo „krnąbrną” familia, która strzeże swojej odrębności. Mamy do czynienia z Wilczymikosami, nie Prusem II. W kierunku rodu Prusów ciążą tylko Będkowscy, na początku XV w. określający się z proklamą Moszczenica, ale później - Prus ${ }^{37}$. Można zauważyć, że Koyszowie i Zacharscy to rodziny raczej uboższe, zaściankowe, słabo poświadczone w źródłach, natomiast od początku XV w. zaczyna się kariera Wspinków (późn. Spinków) ${ }^{38}$, którzy doszli nawet do urzędów senatorskich - była to więc rodzina zainteresowana konsolidacją rodu, dzięki której łatwiej było im się wybić. To ciekawe zjawisko obrazujące różne tendencje i różną świadomość genealogiczną - i polityczną - poszczególnych gałęzi rodu heraldycznego.

Kończąc temat Prusów chciałbym jeszcze na moment powrócić do kwestii Turzynitów. J. Chwalibińska wykazała zupełną odrębność tej małej genealogii39 ${ }^{39}$ Zwrócić uwagę warto na pojawiających się regularnie w źródłach dziedziców Cianowic, którzy do 1472 r. świadczą się półtorakrzyżem z proklamą Turzyna, a od tego roku dopiero - Prus ${ }^{40}$. Chwalibińska sądzi, że nastąpiło to pod wpływem Długosza, który omyłkowo zestawił w Księdze uposażeń półtorakrzyż Turzynitów z półtorakrzyżem Prusów wielkopolskich, a później, w pierwszym polskim herbarzu, Klejnotach, już tylko kontynuował

34 J. Bieniak, Rody..., dz. cyt.; tenże, Heraldyka..., dz. cyt. Ród Wilczychkos był liczącym się, przynajmniej lokalnie, „stronnictwem politycznym", o czym świadczy obecność jego przedstawicieli przy spisywaniu dokumentów lojalnościowych dla Władysława Jagiełły - por. Kodeks Dyplomatyczny Polski, t. II, Warszawa 1852, nr 576 i 578.

${ }_{35}$ K. Potkański, Zapiski herbowe z dawnych ksiag ziemskich, przechowywane w archiwum radomskim i warszawskim, Archiwum Komisji Historycznej, t. III, 1886, nr 77

36 Jakub Zacharski w 1444 r. - K. Potkański, Zapiski..., dz. cyt., nr 83; Andrzej Koysz w 1412 r. - Pokłosie heraldyczne, RTH, 1921-1923, VI, nr 13.

37 SPPP II, nr 2344.

38 J. Chwalibińska, dz. cyt., s. 76-79; J. Szymczak, Śladami Wspinków herbu Wilczekosy, czyli Prus II, „Herald” 1991, II, z. ${ }^{3 / 4}$; O zasadzie protekcyjności wewnątrzrodowej - J. Bieniak, Rody..., dz. cyt., s. 76-77; J. Wroniszewski, Kryteria..., dz. cyt., s. 127-128. Nb. Wspinkowie jako jedni z pierwszych dodali w swym herbie do wilczych kos półtora krzyża, który to znak stawać się zaczął elementem jednoczącym trzy gałęzie rodu (tablica erekcyjna kościoła w Będkowie-P. Mrozowski, Polskie tablice erekcyjne z wieków XIV i XV, „Studia Źródłoznawcze” 1990, XXXII-XXXIII, s. 100. Na dokumencie z 25 I 1434 - por. przyp. 32 - w którym rycerstwo dobrzyńskie zgadza się powołać na tron syna Władysława Jagiełly pieczęć przedstawiającą wilczekosy z półtorakrzyżem przywiesił Jan z Grodzień, z którym Piotr z Będkowa świadczył w procesie Jana Kraszki. Proces odbył się w Krakowie 24 XI 1431, a na rokach obecni byli najwyżsi dostojnicy duchowni i świeccy - widać więc w jakim środowisku obracali się Będkowscy - SPPP II, nr 2344. Pieczęć - F. Piekosiński, Jana Zamoyskiego notaty heraldyczno-sfragistyczne, [w:] tenże, Studya, rozprawy i materyały z dziedziny historyi polskiej i prawa polskiego, t. VII, Kraków 1907, nr 455.

${ }_{39}$ J. Chwalibińska, dz. cyt., s. 100-101, 110-112; szerzej o rodzie s. 80-92.

40 SPPP II, nr 1197; SPPP VII, nr 293, 302, 338, 843, 1114 
wcześniejszą drogę․ Mamy więc ciekawy przykład zmiany proklamy i de facto całego herbu (przy zachowaniu godła!) oraz włączenie niewielkiej grupy krewniaczej do tworzącego się sztucznego rodu.

Widać więc jak utożsamianie herbu (czy to przez Prusów i Turzynitów, czy to przez przywołanych przez Wroniszewskiego Kołmaszów i Czawujów) prowadzi do zacieśnienia więzów krewniaczych - a może jest to tylko wyraz tego zacieśniania. Wroniszewski podaje też odwrotny przykład - w miarę upadku i rozkładu rodu pojawiają się nowe odmiany godła, co toruński badacz zauważył na przykładzie Bogoriów ${ }^{42}$.

Przypadki Kołmaszów i Czawujów, Klizów i Jelitczyków, Wizów i Ostojów skłaniają do poszukiwań kolejnych „rozbitych” rodów. Już W. Semkowicz w 1909 r. ${ }^{43}$, a ostatnio J. Wroniszewski ${ }^{4}$, zwrócili uwagę na tożsamość osób występujących z zawołaniami Larysza i Glezyna. J. Szymański rozdzielił te dwa herby ${ }^{45}$, ale niewątpliwie „,w grę wchodzi jedna rodzina"46, albowiem "taż sama osoba, Piotr z Chechła, występuje raz z zawołaniem Glezyn, drugi raz z Laryszą" ${ }^{\text {"47 }}$. Pomiędzy 1420 a 1453 rokiem Piotr trzykrotnie nazwał się Glezyna, a dwukrotnie Larysząa ${ }^{48}$.

W kontekście przenikania się herbów warto zwrócić uwagę na referat M. Wolskiego o herbie Ogniwo ${ }^{49}$. Przytaczałem za J. Wroniszewskim najbardziej kontrowersyjną zapiskę dotycząca tego rodu (przyp. 14). W innych jako godło pojawia się nie poługryf, ale ogniwo z krzyżem ${ }^{50}$. Do dziś nie zachował się żaden przekaz ikonograficzny ${ }^{51}$, poza odrysem pieczęci Wacława Swoszowskiego, jaki F. Piekosiński zamieścił w swej Heraldyce polskiej wieków średnich ${ }^{52}$. Niewielki ten ród, podobnie jak niektóre poprzednie wspomniane, utożsamiać się zaczął z możniejszymi otaczającymi go genealogiami. Jeden z Lubowlitów, Mikołaj, mimo iż w $1387 \mathrm{r}$. wystawił dokument ze swą rodową proklama, w 1415 r. pisał się jako Strzemieńczyk. Również z herbem Strzemię został zapisany w Księdze uposażeń biskupstwa krakowskiego Piotr Kawalec, syn Michała Kawalca herbu Ogniwo. Stryjeczny brat Piotra został tamże zapisany z herbem Nowina. Jak widać $\mathrm{w}$ ciągu XV w. postępuje dekompozycja rodu, ale raczej nie ze względu na podobieństwo godeł jego i Strzemienia. Nie można łączyć genetycznie obydwu znaków, gdyż „oba herby składają się z zupełnie odmiennych elementó $w^{\prime \prime 53}$ - strzemienia i pierścienia, ogniwa, „zamkniętej formy z wystającymi jakby wąsami" oraz krzyża kawalerskiego. Ostatnia wzmianka o Lubowlitach pochodzi z 1524 r. - ci, którzy nie weszli do innych genealogii prawdopodobnie wymarli.

W tymże tomie referat M. Wolskiego poprzedza praca B. Paszkiewicza i M. Florka, Pieczęć Gedki i herb Bienia z Eososiny ${ }^{54}$. Wykorzystując podobny materiał źródłowy dochodzą do diametralnie

41 Tamże, s. 112

42 J. Wroniszewski, Kryteria..., dz. cyt., s. 128-129.

43 W. Semkowicz, O początkach rodu Laryszów-Glezynów, MH 1909, II, I, s. 39-41.

44 J. Wroniszewski, Proclamatio..., dz. cyt., s. 169-170.

45 J. Szymański, Herbarz..., dz. cyt., s. 122-123 i 168-170.

46 J. Wroniszewski, Proclamatio..., dz. cyt., s. 170.

47 W. Semkowicz, O pochodzeniu..., dz. cyt., s. 40.

48 J. Wroniszewski, Proclamatio..., dz. cyt., s. 170.

49 M. Wolski, Kilka uwag o herbie Ogniwo i rodzie "Lubowlitów", [w:] A. Radzimiński, A. Supruniuk, J. Wroniszewski (red.), Venerabiles, nobiles et honesti. Studia z dziejów Polski średniowiecznej. Prace ofiarowane Profesorowi Januszowi Bieniakowi w siedemdziesiątą rocznicę urodzin i czterdziestopięciolecie pracy naukowej, Toruń 1997.

50 Proclamacio Lubowla, clenodium ignile et crux - SPPP VII, nr 54.

51 Trzy pieczęcie, które podaje J. Szymański, Herbarz, s. 182, należą do innych osób - M. Wolski, dz. cyt., s. 392.

52 F. Piekosiński, Heraldyka..., dz. cyt., s. 267, fig. 444. Nota bene - M. Wolski pisze o Więcławie ze Swoszowic. M. Wolski, dz. cyt., s. 397.

53 M. Wolski, dz. cyt., s. 398.

54 B. Paszkiewicz, M. Florek, Pieczęć Gedki i herb Bienia z Łososiny, [w:] A. Radzimiński, A. Supruniuk, J. Wroniszewski (red.), dz. cyt., s. 351-368 
różnych wniosków - tytułowy herb Bienia Wolski uznał za Ogniwo, Paszkiewicz i Florek zaś za Zarosie, w dodatku połączyli go na zasadzie daleko posuniętej hipotezy z Gedka, kasztelanem sądeckim z pierwszej połowy XIII w. Warto wspomnieć tu uwagę M. Wolskiego, który pisze, że w materiale archeologicznym średniowiecza nie znajdujemy strzemienia kabłąkowego $0^{55}-$ a takie widniałoby w herbie Bienia, gdybyśmy uznali argumentację B. Paszkiewicza i M. Florka. Niemniej jednak autorzy przytaczają ciekawe fakty dotyczące klejnotników Zarosia - wpisują się one w dotychczasowe nasze rozważania. Znów znajdujemy rycerzy określających się mianami, które my uznajemy za nazwy odrębnych herbów i rodów ${ }^{56}$. Herb Zarosie przedstawia strzemię z gwiazdą ${ }^{57}$, ale dwukrotnie opisane jest tylko słowem „strepa” - strzemię. Czy to podstawa do utożsamienia tych dwóch herbów? Wspominałem o częstej niedokładności w opisywaniu herbów, być może i tu zachodzi ten przypadek, zwłaszcza, że mamy do czynienia z rodem niewielkim, zanikającym.

Dotychczasowe przykłady pokazywały, że sumienna kwerenda źródłowa może doprowadzić do poszerzenia wiedzy o mało znanych herbach, a nawet rzucić nieco światła na strukturę społeczną Polski XV-wiecznej. Ale czy tak jest zawsze? W 1439 r. w Samborze oczyścił się z zarzutu chłopskiego pochodzenia Iwan Czyżowski herbu Chmara ${ }^{58}$. Sprowadził dwóch świadków z rodu ojczystego, dwóch z macierzystego i dwóch z obcego. Tylko klejnotników jego matki jesteśmy w stanie zakwalifikować do istniejącego już herbu - Powała, choć występuje tu odmienna proklama Sudkowicz ${ }^{59}$. Pomimo dość dokładnego opisu zarówno Chmary jak i owego „obcego” herbu - nie możemy go zidentyfikować, a podobne wyobrażenia już się nie pojawiają - mimo, iż Iwan często pojawia się w źródłach, miał brata Stanisława ${ }^{60}$ i syna Ihnatko ${ }^{61}$. Źródła przynoszą nam jednak tylko informacje o jego stosunkach majątkowych - częściowo też zapewne towarzyskich. Jesteśmy w stanie zrekonstruować śladowo jego otoczenie, ale nie możemy go przypisać do konkretnego rodu ${ }^{62}$. Bywa po prostu, że źródła mówią tylko to, co chcą i ani słowa więcej.

Podobnie rzecz się ma z herbem Zgraja, wymienianym w Księdze uposażeń biskupstwa kra$k_{\text {owskiego }}{ }^{63}$. Źródło to zawiera wiele pojedynczych wzmianek o rycerzach i ich herbach, dlatego może być z powodzeniem wykorzystane do badań prozopograficznych - choć bywa, że nie jesteśmy w stanie wyjść poza stwierdzenie istnienia danego herbu. Klejnotnicy Zgrai siedzieli w kilku wsiach, na dość zwartym obszarze - podobnie więc jak Lubowlici. S. Dziadulewicz utożsamił herb z Awdańcem, ale w tym momencie jego argumentacja nie przekonuje - opiera się tylko i wyłącznie na domysłach nowożytnych autorów herbarzy ${ }^{64}$. O wiele bardziej prawdopodobne jest utożsamienie Goljana z Chorąbała, ze względu na miejsce wystąpienia herbu ${ }^{65}$ - w Księdze uposażeń pojawia się Żegota de Zaborowye de domo Golyan, zaś w zapiskach sądowych

55 M. Wolski, dz. cyt., s. 398.

56 B. Paszkiewicz, M. Florek, dz. cyt., s. 367-368.

57 F. Piekosiński, Nieznane zapiski heraldyczne z ksiag wiślickich, [w:] tenże, Studya, rozprawy i materyały..., dz. cyt., nr 19.

58 AGZ XIII, nr 1116.

59 Por. J. Szymański, Herbarz..., dz. cyt., s. 204 i 205 i przyp. 1.

60 AGZ XIII, nr 3258, 3259.

61 Tamże, nr 3988.

${ }^{62}$ Wśród wierzycieli Iwana często pojawiają się Amadejowie Mzurowscy, Mikołaj Zawiasa, jakieś stosunki łączyły go też z popem w Wielinicach i Iwanem „Iamvrowiczem” - AGZ XIII, nr 890, 1531, 1973, 3258-9

63 Liber beneficiorum..., dz. cyt., t. II, s. 485, 515, 527, 528, 548, 558; t. III, s. 252

64 S. Dziadulewicz, Ze studyów heraldycznych. 5. Herb Zgraja, MH, V, 1912, 9-10, s. 169-170. W zapiskach krakowskich spotykamy tylko jednego hipotetycznego przodka wymienionych w Liber beneficiorum..., dz. cyt. rycerzy, Sędziwoja Kanimira - w 1402 r. Canimirus de Zircouice zastawia swą część wsi sąsiadowi, Jakuszowi (SPPP II nr 850).

65 S. Dziadulewicz, Ze studyów heraldycznych. 2. Herb Golian, MH, V, 1912, 5-6, s. 95-97. 
Stefan z tejże wsi. Dwóch następnych klejnotników Chorąbały nosi przydomek „Golyan” ${ }^{\prime 66}$. Ale i tu nie możemy wyjść poza to przyporządkowanie. Po prostu źródeł jest za mało.

Dotychczasowa literatura dokonała więc identyfikacji siedmiu godeł: Kliza, Wiza, Kołmasz, Glezyna, Goljan, Moszczenica i Wazanki okazały się odmianami lub proklamami znanych skądinąd, często dobrze poświadczonych, herbów. Nie udałoby się to bez szczegółowych badań genealogicznych (których punktem wyjścia była czasem ponowna kwerenda w źródłach rękopiśmiennych) drobnych rodzin rycerskich. Ten kierunek był już sygnalizowany w literaturze ${ }^{67}$ i zapewne będzie rozwijany.

W dwóch przypadkach mieliśmy do czynienia z oczywistą pomyłka, utożsamieniem dwóch różnych wsi (Będków, Mikułowice) - wskazuje to jak trzeba być ostrożnym w badaniach genealogicznych.

Raz dokonano pomyłki paleograficznej, dzięki czemu może nastąpić zwrot ku źródłom archiwalnym, niewydanym - ich ponowne przejrzenie i opracowanie.

Śledząc takie herby, jak Chmara i Zgraja, stajemy bezradni przed brakiem i milczeniem źródeł (choć w przypadku Chmary mamy potwierdzonych jej klejnotników co najmniej do końca $\left.\mathrm{XV} \mathrm{w} \cdot{ }^{68}\right)$.

Na przykładzie Ogniwa i Zarosia (a także poniekąd Turzyny) mogliśmy prześledzić proces dekompozycji rodu drobnorycerskiego i przechodzenie jego członków do szeregów innej paranteli. Widać jak dawniej bardzo zależało ludziom na umocowaniu w silnej grupie społecznej, mogącej stanowić ochronę i protekcję dla jednostki (choć mamy też przykład odwrotny - Wilczychkos Koyszów i Zacharskich, nie dążących do stworzenia zwartej i silnej grupy społecznej). Szczególnie więc te dwa przypadki wzmocnić mogą teorię o ograniczonym przenikaniu obcych elementów do rodów stricte genealogicznych.

\section{ŹróDŁA}

Akta grodzkie i ziemskie z czasów Rzeczypospolitej Polskiej z archiwum tak zwanego bernardyńskiego we Lwowie, t. XIII, Lwów 1888.

Akta grodzkie i ziemskie z czasów Rzeczypospolitej Polskiej z archiwum tak zwanego bernardyńskiego we Lwowie, t. XVII, Lwów 1901.

Akta grodzkie i ziemskie z czasów Rzeczypospolitej Polskiej z archiwum tak zwanego bernardyńskiego we Lwowie, t. XVIII, Lwów 1903.

Helcel A. Z. (wyd.), Starodawne prawa polskiego pomniki. Z ksiag rękopiśmiennych dotąd nieużytych główniej zaś z ksiag dazwych sądowych ziemskich i grodzkich, t. II, Kraków 1870.

Joannis Długosz, Opera omnia, ed. A. Przezdziecki, t. VIII, Liber beneficiorum dioecesis cracoviensis, t. II, Cracov 1864.

Joannis Długosz, Opera omnia, ed. A. Przezdziecki, t. IX, Liber beneficiorum dioecesis cracoviensis, t. III, Cracov 1864.

Mrozowski P., Polskie tablice erekcyjne z wieków XIV i XV, „Studia Zródłoznawcze” 1990, XXXII-XXXIII.

Piekosiński F., Jana Zamoyskiego notaty heraldyczno-sfragistyczne, [w:] tenże, Studya, rozprawy i materyały z dziedziny historyi polskiej i prawa polskiego, t. VII, Kraków 1907.

Piekosiński F., Nieznane zapiski heraldyczne średniowieczne polskie, głównie sieradzkie, Archiwum Komisji Historycznej Akademii Umiejętności, t. VIII, 1898.

Piekosiński F., Nieznane zapiski heraldyczne z ksiag wiślickich, [w:] tenże, Studya, rozprawy i materyały z dziedziny historyi polskiej i prawa polskiego, t. VII, Kraków 1907.

Pokłosie heraldyczne, „Rocznik Towarzystwa Heraldycznego” 1921-1923, VI.

Potkański K., Zapiski herbowe z dawnych ksiąg ziemskich, przechowywane w archiwum radomskim i warszawskim, Archiwum Komisji Historycznej, t. III, 1886.

66 K. Potkański, Zapiski herbowe, nr 48, 79

67 J. Chwalibińska, dz. cyt., s. 118. Zwłaszcza przedwojenni badacze wykazywali duże zainteresowanie „drobiazgami heraldycznymi", chcąc je koniecznie zakwalifikować do jakiegoś herbu.

68 AGZXVII nr MXXX. 
Rzyszczewski L., Muczkowski A. (wyd.), Kodeks Dyplomatyczny Polski, t. II, Warszawa 1852.

Ulanowski B. (ed.), Starodawne prawa polskiego pomniki. Inscriptiones clenodiales ex libris iudicalibus palatinus cracoviensis, t. VII, Kraków 1885.

\section{LiTERATURA PRZEDMIOTU}

Bieniak J., Heraldyka polska przed Dtugoszem. Uwagi problemowe, [w:] tenże, Polskie rycerstwo średniowieczne, Kraków 2002. Bieniak J., Jeszcze w sprawie genezy rodów rycerskich w Polsce, [w:] tenże, Polskie rycerstwo średniowieczne, Kraków 2002.

Bieniak J., Problemy metodyczne średniowiecznej genealogii w Polsce, [w:] tenże, Polskie rycerstwo średniowieczne, Kraków 2002.

Bieniak J., Rody rycerskie jako czynnik struktury społecznej w Polsce XIII-XV wieku (uwagi problemowe), [w:] tenże, Polskie rycerstwo średniowieczne, Kraków 2002.

Cetwiński M., Wokót „Klejnotów", [w:] Hertel J. (red.), Genealogia. Studia nad wspólnotami krewniaczymi i terytorialnymi wo Polsce średniowiecznej na tle porównawczym, Toruń 1987.

Chwalibińska J., Ród Prusów w wiekach średnich, Toruń 1948.

Dziadulewicz S., Drobiazgi heraldyczne. 5. Herb Ważanki, „Rocznik Towarzystwa Heraldycznego” 1921-1923, VI.

Dziadulewicz S., Ze studyów heraldycznych. 2. Herb Golian, „Miesięcznik Heraldyczny” 1912, V, 5-6.

Dziadulewicz S., Ze studyów heraldycznych. 5. Herb Zgraja, "Miesięcznik Heraldyczny” 1912, V, 9-10.

Dziadulewicz S., Ze studiów nad heraldyką. Herb Piękostki, „Miesięcznik Heraldyczny” 1912, V, 3-4.

Fronczak W., O herbie Piękostki, „Gens" 2007-2008.

Fronczak W., Programy heraldyczne w bẹdkowskim kościele - próba wyjaśnienia, „,Gens” 2005-2006.

Jurek T., Panowie z Wierzbnej, Kraków 2006.

Małecki A., Studya heraldyczne, t. II, Lwów 1890.

Paszkiewicz B., Florek M., Pieczęć Gedki i herb Bienia z Eososiny, [w:] Radzimiński A., Supruniuk A., Wroniszewski J. (red.), Venerabiles, nobiles et honesti. Studia z dziejów Polski średniowiecznej. Prace ofiarowane Proesorowi Januszowi Bieniakowi w siedemdziesiata rocznice urodzin i czterdziestopięciolecie pracy naukowej, Torun 1997.

Piekosiński F., Heraldyka polska wieków średnich, Kraków 1899.

Polaczkówna H., Recenzja W. Wittyg, Nieznana szlachta polska i jej herby, „Miesięcznik Heraldyczny” 1909, II, 5.

Semkowicz W., Długosz jako heraldyk, „Miesięcznik Heraldyczny” 1908, I, 1.

Semkowicz W., O poczatkach rodu Laryszów-Glezynów, „,Miesięcznik Heraldyczny” 1909, II, 1.

Szymański J., Herbarz średniowiecznego rycerstwa polskiego, Warszawa 1993.

Szymański J., Nauki pomocnicze historii, Warszawa 2004.

Szymczakowa A., Drobiazgi heraldyczne z Sieradzkiego, „Rocznik Towarzystwa Heraldycznego nowej serii” 2001, V.

Wolski M., Kilka uwag o herbie Ogniwo i rodzie "Lubowlitów", [w:] Radzimiński A., Supruniuk A., Wroniszewski J. (red.), Venerabiles, nobiles et honesti. Studia z dziejów Polski średniowiecznej. Prace ofiarowane Proesorowi Januszowi Bieniakowi w siedemdziesiata rocznice urodzin i czterdziestopięciolecie pracy naukowej, Toruń 1997.

Wroniszewski J., Kryteria herbowe w badaniach genealogicznych, [w:] Hertel J. (red.), Genealogia. Problemy metodyczne w badaniach nad polskim spoteczeństwem średniowiecznym na tle porównnawczym, Toruń $1982 .$.

Wroniszewski J., Proclamatio alias godlo. Uwagi nad geneza i funkcją zawotan rycerskich w średniowiecznej Polsce, [w:] Spoteczeństwo Polski średniowiecznej, t. 4, Warszawa 1990.

Zawitkowska W., O herbie Pobóg $w$ XV wieku. Na marginesie badań nad dziejami Koniecpolskich w późnym średniowieczu, „Rocznik Towarzystwa Heraldycznego Nowej Serii" 2005, VII.

\section{STRESZCZENIE}

Artykuł prezentuje przegląd literatury - nowszej, ale i przypomina też ustalenia przedwojennych badaczy - na temat herbów drobnego rycerstwa, słabo poświadczonego w źródłach. Znalazły się też w nim pewne własne ustalenia autora, głównie na temat herbów Prus, Chmara i Zgraja. Celem jego jest także ograniczona refleksja źródłoznawcza w sprawie herbów, co do których brakuje wiadomości o ich wyglądzie i ewentualnym genetycznym związku z innym herbem. Poruszono kwestię następujących herbów lub ich zawołań: Kliza, Wiza, Moszczenica, Calina, Wazanki, Piękostki, Ulina, Owada, Czawuja, Kołmasz, Prus I (Turzyna), Prus II (Wilczekosy), Glezyna, Larysza, Ogniwo, Zarosie, Chmara, Zgraja, Goljan. Większość z nich okazała się tożsama z innymi, bardziej znanymi herbami, lub do takiego utożsamienia dążyła. Rzuca to pewne światło na strukturę i reguły rządzące społeczeństwem późnego średniowiecza w Polsce. 
Słowa kluczowe: heraldyka, drobne rycerstwo, odmiany herbowe, zanikanie herbów, społeczeństwo średniowieczne

\section{Vanishing Signs. Is It Possible to Follow the Fortunes of Polish Knightly Coat of Arms with the Help of Medieval Sources?}

\section{Summary}

The paper presents research on some virtually unknown coat-of-arms. It deals with the subject of coat-of-arms, such as Kliza, Wiza, Moszczenica, Calina, Wazanki, Piękostki, Ulina, Owada, Czawuja, Kołmasz, Prus I (Turzyna), Prus II (Wilczekosy), Glezyna, Larysza, Ogniwo, Zarosie, Chmara, Zgraja, Goljan. Most of them are supposed to be variants of well-known coat-of-arms. They also reflect the structure of medieval society in Poland.

Key words: heraldry, small knight-clans, variant of coat-of-arms, disappearance of coat-of-arms, medieval society. 